\title{
Pedagogical Content Knowledge: Teaching Preparation for Pre-Service English Teachers (A Case Study at Universitas Muhammadiyah Semarang)
}

\author{
Siti Aimah ${ }^{1}$, Dwi Rukmini ${ }^{2}$, Mursid Saleh ${ }^{3}$, Dwi Anggani Linggar Bharati ${ }^{3}$ \\ ${ }_{1,2,3}$ Universitas Negeri Semarang, Indonesia
}

\{siti.aimah@unimus.ac.id $\left.{ }^{1}\right\}$

\begin{abstract}
As a crucial need of teaching, pedagogical content knowledge (PCK) should be prioritized by pre-service English teachers for their teaching preparation. It is not only about the knowledge of content, but also about the knowledge of pedagogy which determines the success of their performance of teaching. A good teacher who has a good performance of teaching will have a good awareness of PCK. It means that he must know the subject matter taught and know how to teach it to the students in more understandable manner. This study aims to investigate pre-service English teachers' PCK for their teaching preparation. A case study was employed in which 11 pre-service English teachers of Universitas Muhammadiyah Semarang were involved. Test, observation and document were used to obtain the quantitative and qualitative data. The result showed that PCK which was regarded as a prerequisite of teaching was really required for pre-service English teachers in preparing them for teaching practices. Through PCK, they learnt how well to carry out the instructional process from planning to evaluating effectively.
\end{abstract}

Keywords: content knowledge, pedagogical knowledge, pedagogical content knowledge, preparation, teaching

\section{INTRODUCTION}

Most researchers have conducted the studies on pedagogical content knowledge (PCK) by focusing only on students' understanding [1], [2], [3], [4], [5]. Pedagogical content knowledge is very important to be possessed by pre-service English teachers because they not only have to know the subject matter to teach but also how to teach it in more understandable one to the students [6]. Thus, before practicing their teaching, pre-service English teachers must be equipped with pedagogical knowledge and content knowledge [7], [8] in which they have to understand the concepts, know pedagogical techniques, have knowledge of difficult or easy concept to learn, and understand students' prior knowledge. Those are required by them for practicing their teaching either in microteaching class or in teaching internship in the secondary schools.

Most problems faced by pre-service teachers dealing with their teaching preparation and teaching practice are related to their understanding in designing the lesson plan in which it is a 
part of PCK which covers the ability in choosing the appropriate method and media of learning, designing learning activities to the students, allocating the suitable time to teach, executing the planned lesson in the classroom, managing time and classroom, and mastering teaching material [9], [10], [11], [12], [13], [14].

Those common problems were also faced by pre-service English teachers at Universitas Muhammadiyah Semarang. They had difficulties in designing a lesson plan and executing it into an effective teaching. The problems faced by pre-service English teachers, particularly on the lesson plan that they have to prepare, commonly deal with their understanding of how to construct the learning objectives and indicators which often reverse in writing. Most of them did not understand that in writing the indicator, it must include the dimension of cognitive process and the dimension of knowledge encompassing factual, conceptual, procedural, and metacognitive. Pre-service English teachers commonly copied and pasted the lesson plan downloaded from the internet without being checked and adjusted with the needs. Hence, they could not learn and comprehend every single step that they had to consider. Another problem also deals with their ability in choosing methods of teaching. The method that they had selected was not described clearly and completely in the steps of learning. Therefore, it was difficult to see and observe what learning activities looked like triggering students to be active in the classroom. Consequently, in the teaching practice, most of pre-service English teachers did not involve their students actively through challenging activities which explored students' creativity in the classroom. The problem was also found in the assessment part. In this part, they did not understand the form and the type of assessment that must be used in which it must be based on the indicator and learning objective. Because of inappropriate assessment caused them unable to achieve the learning objective appropriately. Besides that, pre-service English teachers' mastery of subject matter and classroom management were also the other problems faced by them. Because of their lack in mastering the material and managing time and classroom made the students ignored their teaching in the classroom. Their difficulties in interacting with the students also restricted them to involve the students actively in the classroom. Consequently, the atmosphere of the class was not conducive to learn.

Pre-service teachers who are prepared to be professional teachers basically are expected to be able to create an effective teaching to the students. They must be able to use various kinds of materials which are based on students' needs, characteristics and learning styles [15]. Besides, they also require the competences of teaching. The competences required in teacher education basically deal with subject matter (content) knowledge, pedagogical knowledge, and pedagogical content knowledge (PCK) [16], [17], [18].

Teachers initially put PCK separately in which subject matter knowledge is separated from pedagogical knowledge. Both are integrated each other in teaching and learning process in order to create an effective teaching. In this point, teachers must be able how to teach and transform subject matter with the appropriate examples in order to be more understandable to the students [19], [20], [21]. Engaging students actively through some activities exploring their abilities optimally in the classroom is very required to activate teaching and learning process. Therefore, PCK plays an important role for determining the success of teaching.

Considering the importance of PCK in implementing teaching and learning process in the classroom, the purpose of this study aims to investigate Pre-service English teachers' PCK for their teaching preparation. 


\section{METHODOLOGY}

The research design used in this study was a case study. There were 11 pre-service English teachers who enrolled microteaching course in the sixth semester in the academic year of 2018/2019. Pre-service English teachers were demanded to prepare their teaching administration such as lesson plan in which it is part of PCK before practicing their teaching in which it was assessed by three raters. The raters were assigned to assess pre-service English teachers' PCK based on their observation during teaching performance. Therefore, the instruments employed in this study were test, observation and document.

Test of content knowledge (CK) was administered to pre-service English teachers in order to measure their mastery of the subject matter particularly in English. There were 30 questions in which it was restricted to the area of English subject matter by referring to the test administration guidance of 2015 teacher competency testing (kisi-kisi UKG tahun 2015). It also referred to 2013 curriculum in which pre-service English teachers must adjust the curriculum used in the secondary schools when practicing their teaching in real settings.

The second instruments used was observation which was adapted and modified from Jang, Guan \& Hsieh [8] in which it was focused on four main elements: Subject Matter Knowledge (SMK), Instructional Representation and Strategies (IRS), Instructional Objects and Context (IOC), and Knowledge of Students' Understanding (KSU). Three raters were involved in which they were assigned to assess pre-service English teachers' PCK by dropping their scores ranging from 1 (very poor), 2 (poor), 3 (good), to 4 (very good), and write their feedback based on their findings during observation.

To support the data of PCK, lesson plan created by pre-service English teachers was also employed. The raters assessed the lesson plan based on the scoring sheet used in teacher professional education (Pendidikan Profesi Guru) ranging from 1 (not found), 2 (incomplete), to 3 (complete).

The quantitative data were analyzed by using descriptive statistics in which maximum score, minimum score, mean, and standard deviation were presented. Meanwhile, the qualitative data were analyzed descriptively to support the quantitative data obtained.

\section{FINDINGS AND DISCUSSION}

In order to measure pre-service English teachers' PCK, test of content knowledge (CK) was firstly administered to them in order to measure their understanding about the subject matter i.e. English. The result of test of $\mathrm{CK}$ is presented in Table 1.

Table 1. The Result of Descriptive Statistical Analysis of Content Knowledge

\begin{tabular}{lccccc} 
& N & Min & Max & Mean & Std. Deviation \\
\hline $\begin{array}{l}\text { Content } \\
\text { Knowledge }\end{array}$ & \multirow{2}{*}{11} & 26.7 & 86.7 & 63.34545 & 18.8568 \\
& & & & & \\
\hline
\end{tabular}


From Table 1, it could be seen that the minimum score of CK is 26.7 (poor) and the maximum score is 86.7 (very good). Besides obtaining the minimum and the maximum scores, the mean and the standard deviation of pre-service English teachers' CK is also presented. From 11 students, there were 2 pre-service English teachers who were in poor category and 2 preservice English teachers who got fair category. Meanwhile, 6 pre-service English teachers obtained good category, and only 1 pre-service English teacher who achieved very good category. It means that the average of pre-service English teachers' CK is good in which the average score is 63.3 with the standard deviation of 18.8 .

The result of CK strengthens the needs of mastering the subject matter that must be possessed by all teachers in carrying out the instructional process. It is in alignment with Kleickmann, Richter, Kunter, Elsner, Besser, Krauss \& Baumert [22] that CK is related to teachers' understanding of subject matter taught. It is often regarded as a prerequisite of PCK [23]. To be English teachers, pre-service English teachers have to know what is going to teach, in this case is about English. It is in line with Andrews [24] and Suryani [25] pre-service English teachers need to possess CK that is the knowledge about English language. The CK which was administered to them refers to Kisi-kisi UKG 2015 which is also closely related to 2013 curriculum used in the secondary schools. This knowledge about English was used by preservice English teachers in transferring the subject matter to the students.

Besides mastering the subject matter, what is required by pre-service English teachers for preparing their teaching is designing their lesson plan. Lesson plan is regarded as the most important thing to be prepared by pre-service English teachers since they have to decide what and how their students should learn [26]. The following is the result of lesson plan.

Table 2. The Result of Descriptive Statistical Analysis of Lesson Plan

\begin{tabular}{lcccc} 
& N & Min & Max & Mean \\
\hline Lesson Plan & 11 & 2.19 & 2.6 & 2.34
\end{tabular}

From Table 2, it could be seen that the average score of lesson plan is 2.34 (good) with the minimum score of 2.2 and the maximum score of 2.6. Even though they were in good category, many components could not be found from their lesson plan. Based on the analysis of lesson plan, most pre-service English teachers did not really understand how to design a lesson plan of 2013 curriculum well. They did not know how to construct the basic competence (KD) which covers attitude, knowledge, and skill, the indicators which must be arranged by using operational verbs by describing the dimension of cognitive process (C-1 to C-6) and the dimension of knowledge encompassing factual, conceptual, procedural and metacognitive, and the learning objectives in which they are used to achieve the indicators. In writing the indicators and the learning objectives, they commonly did not consider those components. Unsurprisingly, they only copied and pasted the lesson plan downloaded from the internet without being checked and adjusted with the students' needs.

The ability of pre-service English teachers in presenting learning material in a lesson plan also did not show satisfactory result. Nobody presented the material in details containing the knowledge of factual, conceptual, procedural, and metacognitive. Those were required to help them in presenting the material to be taught to the students clearly in order to achieve the learning objectives. Even some of them did not provide the material in a lesson plan. Therefore, it was difficult to see whether or not the material could achieve the intended learning objective.

Pre-service English teachers also often ignored to provide the information clearly and completely dealing with the use of media, tools, and sources. They did not realize the importance of 
using them in which those must be based on students' characteristics, and the needs of achieving learning objective, indicator and students process of learning.

The next point of lesson plan which is commonly the main problem faced by pre-service English teachers is constructing the steps of learning. At this point, steps of learning cover opening, main activities, and closing. In describing the session of opening, pre-service English teachers did not have difficulties in describing the activities within it. Almost all of them described completely the activities such as preparing students' condition, explaining the relevance of the previous material with the next material, explaining the learning objective, and explaining the activities carried out in the classroom. However, in describing main activities, pre-service English teachers commonly did not understand that those were used to achieve the learning objective. They were thinking about how to give the interactive and attractive teaching to the students, but ignoring what virtually the learning objective was. Therefore, learning objective and steps of learning were not related each other. This condition is compounded with the way they described the activities in the session of closing. Commonly, they only formulated the conclusion of the material taught, and explained for further activity without being provided with the assessment and feedback. At this point, some pre-service English teachers had difficulties in differentiating between the type and the form of assessment. Consequently, they did not mention what type of assessment used. Some of them also did not know that the form of assessment must be based on 2013 curriculum containing attitude, knowledge, and skill. From 11 pre-service English teachers, it was found that there were only 8 of them who provided the form of assessment of attitude and knowledge, and completed with the scoring rubric. However, they commonly did not consider the conformity between the form of assessment with the intended learning objective. Thus, the assessment provided could not be used to achieve the learning objective.

Meanwhile, pre-service English teachers' PCK was assessed by focusing on four main points: 1) Subject Matter Knowledge (SMK) which refers to the extent to which pre-service English teacher demonstrates a comprehension of subject matter, 2) Instructional Representation and Strategies (IRS) which deals with the extent to which pre-service English teacher uses analogies, examples and explanation, and selects the appropriate strategies of teaching which are beneficial to the teaching of content, 3) Instructional Objects and Context (IOC) which includes knowledge about the aim and process of education, learning atmosphere, teacher's attitudes, and knowledge of classroom management, and 4) Knowledge of Students' Understanding (KSU) which refers to the extent to which pre-service English teacher evaluates students' understanding before and during, and at the end of teaching and learning process [8]. The following table is the result of pre-service English teachers' PCK.

Table 3. The Result of Pedagogical Content Knowledge

\begin{tabular}{lccccc}
\hline No of PSET & SMK & IRS & IOC & KSU & $\begin{array}{c}\text { Total Score of } \\
\text { PCK }\end{array}$ \\
\hline PSET1 & 1.8 & 2.1 & 2.1 & 2.3 & 2.1 \\
PSET2 & 2.1 & 2.1 & 2.1 & 1.8 & 2.03 \\
PSET3 & 2.0 & 2.3 & 2.2 & 2.0 & 2.13 \\
PSET4 & 2.4 & 2.7 & 2.9 & 2.7 & 2.7 \\
PSET5 & 2.1 & 2.4 & 2.5 & 2.2 & 2.35 \\
PSET6 & 2.5 & 2.7 & 2.9 & 2.4 & 2.62 \\
PSET7 & 2.2 & 2.1 & 2.2 & 2.2 & 2.2 \\
PSET8 & 2.2 & 2.4 & 2.5 & 2.3 & 2.35 \\
PSET9 & 2.7 & 2.6 & 2.9 & 2.6 & 2.7 \\
PSET10 & 2.1 & 2.3 & 2.2 & 2.1 & 2.2 \\
PSET11 & 2.5 & 2.4 & 2.5 & 2.2 & 2.4 \\
Average & $\mathbf{2 . 2}$ & $\mathbf{2 . 4}$ & $\mathbf{2 . 4}$ & $\mathbf{2 . 2}$ & $\mathbf{2 . 3 4}$ \\
\hline
\end{tabular}


From Table 3, it shows that the lowest score of PCK is 2.03 and the highest score is 2.7 . Meanwhile, the average score of it is 2.34. From each component of PCK, the result shows that 11 pre-service English teachers are in good category. However, dealing with their subject matter knowledge (SMK), some of them did not comprehend the subject matter well. It was proven with the way they transferred the subject matter in which they often ignored with the theories or principles of the subject developed. In fact, the content was not delivered clearly. It influenced them in giving unclear instructions that made the students uncontrolled during the class. Most of them also had difficulties in posing the questions to the students. It happened because they did not prepare and make a list of questions to be posed to the students. Consequently, they could not see whether or not the students had difficulties in understanding the content taught. Most of them also did not focus on the skill that would like to achieve from the students. It was seen from their lesson plan in which in formulating the learning objectives, they did not highlight clearly what skill that needed to focus on. It made them unable to select the appropriate content to the students. Therefore, the content was not delivered systematically. Whereas, SMK is often regarded as a prerequisite of teaching. Pre-service English teachers had to have a deep understanding about the subject taught to the students. It is in line with Faisal [20] that teachers need to understand the material not only theoretically but also practically in order to be shared with the students systematically.

The next point which is still related to SMK is instructional representation and strategies (IRS) in which at this point, the average score is 2.4. Most pre-service English teachers did not focus on the skill that would like to achieve. They had difficulties in using analogies and/or examples to explain the concepts related to the content. Some of them who taught writing to the students, generally did not facilitate the students with the process of learning writing. It could be seen from the way they taught in which they did not provide the writing process including what stage that should be started from. It made the students confused because in one side they were demanded to create a text, but on another side they were not given examples of how to write. IRS is also closely related to knowledge of pedagogy in which pre-service English teachers must be able to select the appropriate media, method and strategies of teaching in the learning process. It is in line with Faisal [20] that knowledge of pedagogy deals with the knowledge of strategies, approaches, methods and learning techniques to deliver the subject matter to the students. At this point, in order to help the students in understanding the content, most pre-service English teachers had also provided the students with the use of technology such as video. However, some of them did not consider and prepare what must be done by the students while they were watching video. There were no clear instructions given at the beginning making the students only watched the video without knowing what to find. It was because they previously did not prepare and make a list of instructions/questions to the students. This condition made the students not really interested in the class because their activities were not structured well.

In the component of instructional objective and context (IOC), the average score achieved is 2.4. At this point, what is needed by pre-service English teachers is knowledge of curriculum which covers knowing the learning objective, the content or the subject matter taught, and knowing the method used in teaching and learning process. It is in alignment with the Law number 20 year 2003 [27], and the regulation of MoNE number 16 year 2007 [28], that teachers have to know the goal of learning, the content or the subject matter, learning material, and the method used as a guideline in implementing teaching and learning process. From the result of IOC shows that all pre-service English teachers were good in creating learning atmosphere to promote the students' interest, paying attention to the students' reaction during class, and 
providing an appropriate interaction with the students. However, they did not understand the learning objectives that must be achieved. Some of them did not explain clearly to the students what must be learnt and achieved from the content taught. It was unsurprisingly since in their lesson plan, they also had problems in constructing the learning objectives. Some of them who constructed the learning objectives in their lesson plan by focusing on writing skill, for example, were not consistent in achieving it when carrying out the instructional process in which they merely focused on speaking skill. It shows that their understanding about the objectives of learning was still poor. Therefore, in teaching learning process, they could not able to make the students clearly understand the objectives of learning.

The last component of PCK is knowledge of students' understanding (KSU) in which the average score is 2.2 which is the same with SMK. At this point, some pre-service English teachers only focused on group activities facilitating them to discuss and interact with the others. It was also found that some of them did not give instructions clearly what needed to do during discussion making the students confused. Some of them also did not checked the students' difficulties in learning through group discussion and let them learnt by themselves without assisting them intensively. They also did not evaluate the students' understanding by posing some questions related to the content. It shows that their awareness of preparing their teaching needed to be improved. They needed to make a list of questions that would help them in evaluating the students' understanding of the content. Therefore, knowledge of learners is very crucial for teachers in carrying out the instructional process in which it would help them easier in identifying the needs of teaching tailored to the students' needs. It is in line with Kidwell \& Triyoko [29], Rahman, Scaife, Yahya \& Jalil [30], and Shulman [31] that teachers must possess the understanding of learners' personal characteristics, needs, learning styles, interest, motivation, social and cultural background, what learners know, learners do, learners are going to understand, and learners' problems of learning.

PCK becomes the most important thing to be possessed by pre-service English teachers in teaching preparation. They need not only to have knowledge of content, but also to have knowledge of pedagogy which also covers knowledge of curriculum and learners. As a prerequisite of teaching, PCK must be prioritized in which pre-service English teachers must begin by preparing and designing their lesson plan appropriately in order to create an effective teaching. Through lesson plan, pre-service English teachers will get easier in reflecting and evaluating of what they are going to do and what they are going to give to the students. By having PCK, pre-service English teachers will also have knowledge of how to implement the instructional process from planning to evaluating well. However, teaching experiences also influence their PCK. It is in line with Van Driel, Jong, \& Verloop [32] that PCK is mostly influenced by pre-service teachers' teaching experiences. Only by mastering the content is not enough for them to teach. However, they need to have knowledge of pedagogy in which they learn how to transfer the material in more understandable to the students and learn how to manage time and classroom effectively. In order their PCK becomes better, it is needed for them to have more experiences of teaching.

\section{CONCLUSIONS}

The aim of this study is to investigate pre-service English teachers' PCK for their teaching preparation. We found that the average of 11 pre-service English teachers' CK is good. However, good CK does not always determine their success of teaching. Meanwhile, from the result of analysis of lesson plan, the average of them needs to improve their understanding in designing lesson plan. Lesson plan which is a part of teaching administration in which it is also 
part of PCK plays an important role in determining how well they learn how to carry out the instructional process from planning to evaluating. Through lesson plan, it enables them to firstly evaluate and reflect what are going to do with their students with the materials prepared effectively. The same condition happens to their PCK in which many components of it must be developed in order they are able to implement the instructional practices well. Thus, PCK which is prerequisite of teaching should be facilitated through more activities in teaching preparation and teaching experiences in order to better. Through teaching preparation and teaching experiences, pre-service English teachers learn how to teach the material systematically to the students in more understandable manner, learn how to manage time and classroom effectively so that the classroom atmosphere is more conducive to learn, and learn how to achieve the intended learning objective.

\section{References}

[1] J. Ergönenç, K. Neumann, \& H. E. Fischer, "The Impact of Pedagogical Content Knowledge on Cognitive and Student Learning," Research Gate, pp. 137-151, 2014.

[2] M. M. Keller, K. Neumann, H. E. Fischer, "The Impact of Physics Teachers' Pedagogical Content Knowledge and Motivation on Students' Achievement and Interest," Journal of Research in Science Teaching, 2016.

[3] R. Olfos, T. Goldrine, \& S. Estrella, "Teachers' Pedagogical Content Knowledge and Its Relation with Students' Understanding," Revista Brasileira de Educacao, vol. 19, no. 59, pp. 913-944, 2014.

[4] A. Widodo, "Teacher Pedagogical Content Knowledge (PCK) and Students' Reasoning and Wellbeing," IOP conference Series: Journal of Physics: Conference Series, 812 $012119,2017$.

[5] Y. Yang, X. Liu, \& J. A. Gardella, "Effects of Professional Development on Teacher Pedagogical Content Knowledge, Inquiry Teaching Practices, and Student Understanding of Interdisciplinary Science," Journal of Science Teacher Education, 1573-1847, 2018.

[6] L. S. Shulman, "Those Who Understand: Knowledge Growth in Teachin," Educational Researcher, vol. 15, no. 2, pp. 4-14, 1986.

[7] J. Gess-Newsome, "Pedagogical Content Knowledge: An Introduction and Orientation," In J. Gess-Newsome \& N. G. Lederman (Eds.) "PCK and Science Education," pp. 3-17, 1999. Netherlands: Kluwer Academic Publishers.

[8] S. J. Jang, S. Y. Guan, \& H. F. Hseieh, "Developing an Instrument for Assessing College Students' Perceptions of Teachers' Pedagogical Content Knowledge," Procedia Social and Behavioral Sciences. vol. 1, pp. 596-606, 2009.

[9] I. P. P. Adi, "Sistem Evaluasi dan Kesiapan Pelaksanaan PPL-Real di Sekolah Mitra," Jurnal Pendidikan Indonesia, vol. 4, no. 2, pp. 657-665, 2015.

[10] R. D. Afrilianti, M. Ulfah, \& A. Achmadi, "Persepsi Guru Pamong terhadap Keterampilan Dasar Mengajar Mahasiswa PPL Prodi Pendidikan Ekonomi di SMK Pontianak," Jurnal Pendidikan dan Pembelajaran Untan, pp. 1-13, 1996.

[11] Bertus, "Persepsi Guru Pamong terhadap Kompetensi Profesional Mahasiswa Pendidikan Ekonomi yang Melakukan PPL 2 di SMK 1 Pontianak," Artikel Penelitian, 2018. Retrieved from file://C:/Users/X200MA/Downloads/25114-75676578640-1-PB.pdf

[12] S. Ghanaguru, P. Nair, \& C. Yong, "Teacher Trainers' Beliefs in Microteaching and Lesson Planning in a Teacher Training Institution," The English Teacher, vol. XLII, no. 2, pp. 104-116, 2013 
[13] B. Gorgoretti, \& O. Pilli, "Pre-Service Teachers' View on the Effectiveness of Teaching Practice Course," Procedia - Social and Behavioral Sciences, vol. 47, pp. 812-817, 2012.

[14] H. S. Tokmak, \& T. Karakus, "ICT Pre-service Teachers' Opinions about the Contribution of Initial Teacher Training to Teaching Practice," Contemporary Educational Technology, vol. 2, no. 4, pp. 319-332, 2011.

[15] S. Shohani, A. Azizifar, H. Gowhary, \& A. Jamalinesari, "The Relationship between Novice and Experienced Teachers' Self-Efficacy for Personal Teaching and External Influences," Procedia - Social and Behavioral Sciences, vol. 185, pp. 446-452, 2015.

[16] S. R. Ghazi, G. Shahzada, M. T. Shah, \& M. Shauib, "Teacher's Professional Competencies in Knowledge of Subject Matter at Secondary Level in Southern Districts of Khyber Pakhtunhwa, Pakistan," Journal of Educational and Social Research, vol. 3, no. 2, pp. 453-460, 2013.

[17] S. Kourieos, "The Knowledge Base of Primary EFL Teachers-Pre-service and In-service Teachers' Perception," Journal of Language Teaching and Research, vol. 5, no. 2, pp. 291-300, 2014.

[18] H. G. Yüksel, “Teachers of future: Perceived Teaching Competences and Visions of Preservice English Language Teachers," International Journal of Human Sciences. vol. 11, no. 2, pp. 27-39, 2014.

[19] J. H. Driel, N. Verloop, \& W. Vos, “Developing Science Teachers' PCK," Journal of Research in Science Teaching, vol. 35, no. 6, pp. 673-695, 1998.

[20] Faisal, "Pedagogical Content Knolwedge in Indonesian English Language Teaching," Asia Pacific Journal of Multidisciplinary Research, vol. 3, no. 5, pp. 103-110, 2015

[21] A. N. Geddis, "Transforming Subject-Matter Knowledge: The Role of Pedagogical Content Knowledge in Learning to Reflect on Teaching," International Journal of Science Education, vol. 15, no. 6, pp. 673-683, 1993.

[22] T. Kleickmann, D. Richter, M. Kunter, J. Elsner, M. Besser, S. Krauss, \& J. Baumert, "Teachers' Content Knowledge and Pedagogical Content Knowledge: The Role of Structural Differences in Teacher Education," Journal of Teacher Education, vol. 64, no. 1, pp. 90-106, 2013.

[23] P. J. Friedrichsen, S. K. Abell, E. M. Pareja, P. L. Brown, D. M. Lankford, \& M. J Volkmann, "Does teaching experience matter? Examining biology teachers' prior knowledge for teaching in an alternative certification program," Journal of Research in Science Teaching, vol. 46, pp. 357-383, 2009.

[24] S. Andrews, "Teacher Language Awareness and the Professional Knowledge Base of the L2 Teacher," Language Awareness, vol. 12, no. 2, pp. 81-95, 2003.

[25] B. F. Suryani, "The Impact of Microteaching Lesson Study on English as a Foreign Language (EFL) Student Teachers. A Case of the EFL Student Teachers at Muria Kudus University," Doctoral Dissertation. Universitas Negeri Semarang. Semarang, 2017.

[26] Cicek \& H. Tok. "Effective Use of Lesson Plans to Enhance Education in U.S. and Turkish Kindergarten thru 12th Grade Public School System: A Comparative Study," International Journal of Teaching and Education, vol. 2, no. 2, pp. 10-20, 2014.

[27] The Law of Republic of Indonesia Number 20 Year 2003 on the National Education System. Jakarta.

[28] The Regulation of the Minister of National Education of Republic Indonesia Number 16/2007 on Teacher Academic Qualification Standard and Competency. Jakarta.

[29] T. J. Kidwell, \& H. Triyoko, "Implementing a Student-Centered Pedagogy: Doing so in the Indonesian Teaching-Learning Context,” Register, vol. 5, no. 1, 2012. 
[30] F. A. Rahman, J. Scaife, N. A. Yahya, \& H. A. Jalil, "Knowledge of Diverse Learners: Implications for the Practice of Teaching," International Journal of Instruction, vol. 3, no. 2, 2010.

[31] L. S. Shulman, "Knowledge and Teaching: Foundations of the New Reform," Harvard Educational Review, vol. 57, no. 1, pp. 1-21, 1987.

[32] J. H. Van Driel, O. De Jong, \& N. Verloop, "The development of preservice chemistry teachers' pedagogical content knowledge," Science Education, vol. 86, pp. 572-590, 2002. 